\title{
PROSES INTERVENSI POLITIK PADA PENGANGKATAN SEKRETARIS KPU KOTA PADANG
}

\author{
Atika Verina1), Nursyiwan Efendi,2), Aidinil Zetra $^{3)}$ \\ 1,2,3) Megister Kosentrasi Tata Kelola Pemilu Fakultas Ilmu Sosial Dan Ilmu Politik \\ Universitas Andalas, Padang, Indonesia
}

\begin{abstract}
Abstrak
Pengangkatan Sekretaris KPU Kota padang tahun 2015 yang dilaksanakan di Provinsi Sumatera Barat adanya intervensi politik yang dilakukan oleh pejabat-pejabat politik yang tidak sejalan dengan semangat netralitas birokrasi dan aturan perundangan yang berlaku dalam manajemen birokrasi publik. diduga mengandung beberapa cacat demokrasi. Tulisan ini mendeskripsikan temuan adanya praktek-praktek politik yang tidak sesuai dengan nilai-nilai demokrasi. Hasil penelitian ini mengungkapkan terdapat sejumlah Intervensi Politik Terhadap KPU Kota Padang Dalam Pengangkatan Sekretaris KPU Kota Padang, Kepentingan Politik Khususnya Dalam Proses Penyelenggara Pemilu Dibalik Intervensi Yang Dilakukan Pemda Kota Padang Terhadap KPU Kota Padang, Dampak Intervensi Politik Pemda Kota Padang Terhadap KPU Kota Padang
\end{abstract}

Kata kunci: Intervensi, politik,Sekretaris,KPU, Padang.

*CorrespondenceAddress : verinaatika2@gmail.com

DOI : 10.31604/jips.v6i2.2019.267-281

(C)2019 Fakultas Keguruan \& Ilmu Pendidikan UM-Tapanuli Selatan 


\section{Pendahuluan}

Undang-Undang Nomor 15 Tahun 2011 Tentang Pemilu diubah dengan Undang-Undang Nomor 7 Tahun 2017 tentang Pemilu, Bagian Kesembilan Kesekretariatan Paragraf 1 susunan, pasal 55 menyebutkan "Untuk membantu kelancaran tugas dan wewenang KPU, KPU Provinsi dan KPU Kabupaten/Kota, dibentuk Sekretariat Jendral KPU, Sekretariat KPU Provinsi dan Sekretariat KPU Kabupaten/Kota". Sekretaris KPU adalah komponen penting yang harus dan wajib ada dalam menunjang dan membantu kelancaran tugas dan wewenang KPU. Sebagaimana dimaksud Pasal 56 ayat 1 yang menyebutkan bahwa hubungan antar sekretariat KPU adalah hirarki dengan Sekretaris KPU Provinsi dan Sekretaris KPU Kabupaten/Kota. Didalam Pasal 56 ayat 2 menyebutkan bahwa Kepegawaiannya berada dalam satuan manajemen kepegawaian yang berarti berjalan sendiri terkhusus mengabdi di KPU tanpa ada keterikatan dengan Pemerintah Kota selaku induk kepegawaiannya.

Berdasarkan ketentuan pasal 68 ayat 1 dan ayat 2 tugas dan kewenangan KPU Kota Padang adalah memfasilitasi KPU Kota Padang dalam semua tahapan penyelenggaraan pemilu. Dalam hal ini, tugas Sekretaris adalah memfasilitasi KPU menyangkut kebutuhan anggaran dalam kerangka besar untuk menyelenggarakan pemilu. Selain dukungan anggaran, Sekretaris KPU juga memberikan dukungan teknis administratif seperti penyediaan suratmenyurat, staf pelaksana administrasi dan SDM lainnya untuk membantu kelancaranpendistribusian perlengkapan penyelenggaraan pemilu. (Ramlan Surbakti, Kris Nugroho. 2015)

Dalam pengisian kekosongan Jabatan Sekretaris KPU Kota Padang, telah dilaksanakan berdasarkan mekanisme dan aturan yang berlaku. Berdasarkan Surat Keputusan Walikota Padang Nomor: 821.21.013/SKBKD/2015 tentang Pengangkatan, Pemindahan dan Pemberhentian PNS Dalam dan dari Jabatan Struktural Eselon III dan IV di Lembaga Pemerintah Kota Padang. Drs. Djunardi, M.M sebagai Sekretaris KPU Kota Padang diberhentikan dengan hormat dari jabatan Sekretaris KPU Kota Padang. Dengan ditariknya Sekretaris KPU Kota Padang secara tiba-tiba oleh Pemda Kota Padang, maka terjadilah kekosongan pimpinan, yang mengakibatkan terganggungnya pertanggungjawaban administrasi dalam hal penyusunan 
program anggaran serta dukungan teknis lainnya.

Pemda Kota Padang
mengusulkan dan memberikan rekomendasi tiga (3) orang nama yang akan dicalonkan sebagai Sekretaris KPU Kota Padang.

$$
\text { Tahap selanjutnya Calon }
$$
sekretaris KPU Kota Padang menyiapkan seluruh persyaratan administrasi yang diminta dan mengikuti seluruh rangkaian tahapan fit and propertestserta uji kelayakan. Berdasarkan hasil fit and propertestdan uji kelayakan yang telah dilaksanakan, selanjutnya KPU Kota Padang mengirimkan seluruh berkas administrasi dari awal koordinasi sampai pada hasil fit and propertestdan hasil uji kelayakan yang dilaksanakan, ke Sekjen KPU RI melalui Sekretaris KPU Provinsi Sumbar. Hasil penentuan akhir ditetapkan dan diputuskan oleh Sekjen KPU RI berdasakan ketentuan peraturan perundang-undangan. Sekjen KPU RI memilih, menetapkan dan memutuskan Junita Witri, S.STP, M.Si sebagai Sekretaris KPU Kota Padang dengan menerbitkan Surat Keputusan Nomor : 281/Kpts/setjen/TAHUN 2015 tentang Pemberhentian dan Pengangkatan Sekretaris KPU Kota Padang Provinsi
Sumatera Barat dan memerintahkan KPU Kota Padang untuk mengagendakan pelantikan melalui KPU Provinsi Sumatera Barat.

Berdasarkan hal tersebut KPU Kota padang segera menindaklanjuti perintah Sekjen KPU RI dengan mempersiapkan seluruh administrasi untuk proses pelantikan dan mengirimkan tembusan Surat Keputusan Sekjen KPU RI kepada Walikota Padang. Namun Walikota Padang menolak Keputusan Sekjen KPU RI dan mengatakan bahwa Walikota Padang tidak mengizinkan Junita Witri, SSTP. M.Si untuk menghadiri pelantikan.

Dengan kondisi yang ada maka KPU Kota Padang berada dalam situasi ketidak pastian karena kekosongan pimpinan. Kekosongan jabatan Sekretaris KPU Kota Padang, menjadi masalah yang sangat mendesak terhadap kebutuhan di lembaga KPU Kota Padang berkenaan dengan uang kehormatan (gaji) komisioner KPU Kota Padang, terhambatnya pencairan anggaran yang digunakan untuk menunjang seluruh kegiatan tahapan Pemilihan Gubernur Tahun 2015, serta masalah teknis administrasi yang juga mengharuskan adanya peran Sekretaris. Persoalan menyangkut pengangkatan Sekretaris KPU Kota Padang merupakan 
bentuk intervensi politik yang dikemukakan oleh Pemda Kota Padang. Dibalik intervensi tersebut ada kepentingan politik dari Pemda Kota Padang dalam hal memuluskan administrasi politik berikutnya bagi pimpinan daerah.

Walikota Padang menolak Keputusan Sekretaris Jendral KPU yang menetapkan Junita Witri, S.STP, M.Si sebagai Sekretaris KPU Kota Padang, dengan alasan bahwa Fauzil Mahfud, SH merupakan Calon Nomor urut 1 (satu) yang harus ditetapkan sebagai Sekretaris KPU Kota Padang dan bukan berdasarkan keputusan yang telah ditetapkan oleh Sekretaris Jendral KPU, sehingga hal ini dimungkinkan terjadinya intervensi politik oleh pejabat politik.

Berdasarkan latar belakang dan asumsi yang dibangun maka pertanyaan penelitian ini adalah:

1. Bagaimana proses terjadinya intervensi politik pada pengangkatan Sekretaris KPU Kota Padang?

2. Apa kepentingan politik khususnya dalam proses penyelenggaraan pemilu dibalik intervensi yang dilakukan Pemda Kota Padang terhadap KPU Kota Padang?

\section{METODE PENELITIAN}

Metode penelitian yang digunakan dalam penelitian ini adalah kualitatif dengan pendekatan studi kasus. Studi kasus merupakan suatu pendekatan dengan memusatkan perhatian pada suatu kasus secara intensif dan terinci dengan tujuan mempertahankan keutuhan objek yang diteliti(Nurul Ulfatin. 2017)

Penelitian ini menggunakan data primer dalam bentuk arsip-arsip berupa jurnal, paper, dan berita media massa tentang dinamika dan fenomena pilkada serentak di Indonesia khususnya terkait dengan pilkada serentak 2017 yang akan menunjang hasil yang diteliti. Dalam penelitian ini diperoleh dari hasil kajian literatur yang dilakukan oleh penulis serta dari studi pustaka.

Sumber data yang dugunakan adalah data Primer, dan data sekunder, Data primer yang digunakan untuk studi kasus ini berasal dari hasil wawancara mendalam denganAnggota KPU, Sekretariat KPU Kota Padang danorangorang pada instansi Pemda Kota Padang serta informan inti. Kriteria informan yang akan diwawancarai adalah yang secara langsung terlibat penuh pada proses perekrutan Sekretaris KPU Kota Padang. 
HASIL DAN PEMBAHASAN

Intervensi Politik Terhadap KPU Kota Padang Dalam Pengangkatan Sekretaris KPU Kota Padang

$$
\text { Pada dasarnya terjadinya }
$$
politisasi dalam birokrasi,tidak dapat dilepaskan dari kegiatan politik terutama dalam pemerintahan. Intervensi politikdapat dilakukan oleh pejabat politik itu sendiri, seperti kepala daerah maupun anggota legislatif, bahkan dimungkinkan juga dilakukan oleh para pejabat birokrat, hal tersebut sering terjadi menjelang dan pada saat tahapan Pemilu berlangsung, di mana komunitas darikelompok yang berkepentingan memanfaatkan penggunaan politisasi birokrasi.

Birokrasi sebagaimana dimaksudkan di atas, menurut Said adalah sistem administrasi dan pelaksanaan tugas keseharian yang terstruktur dalam sistem hierarki yang jelas, dilakukan dengan aturan yang tertulis yang dilakukan oleh bagian tertentu yang terpisah dengan bagian lainnya, oleh orang yang di pilih karena kemampuan dan keahlian di bidangnya.(Said, M. Mas'ud. 2007)

Politisasi birokrasi merupakan gejala yang melibatkan birokrasi secara langsung dan terang-terangan untuk menjadi pendukung dan anggota organisasi peserta pemilu guna memperoleh atau mempertahankan kekuasaan di parlemen dan eksekutif. Dalam konteks Pilkada, definisi tersebut berarti keterlibatan birokrasi secara langsung untuk menjadi pendukung pasangan calon kepala daerah guna mendapatkan atau mempertahankan kekuasaan di lembaga eksekutif (Syafuan Rozi. 2006)

Pada dasarnya birokrasi itu tidak dapat dipisahkan dari keberadaan organisasi pemerintahan dan politik, karena dia merupakan suatu sistem untuk mengatur organisasi agar diperoleh pengelolaan yang lebih efisien, rasional, dan efektif.

Beranjak dari hal di atas, jika dikaitkan dengan pola rekrutmen sebagai pintu pertama dalam manajemen SDM ternyata tidak selamanya digunakan sebagai pangkal penempatan dan pengembangan SDM. Dalam beberapa hal kenyataan ini akan ditunjukkan dalam kasus promosi, mutasi dan penempatan seperti yang terjadi dalam kasus penempatan PNS daerah yang dipekerjakan pada instansi KPU Kota Padang Tahun 2015.

Dalam proses rekrutmen PNS daerah yang diperkerjakan pada lembaga KPU Kota Padang dilaksanakan 
sesuai dengan peraturan perundangundangan yang berlaku. Dari hasil seleksi yang dilaksanakan calon nomor urut 1 (satu) yang memiliki nilai tertinggi, namun pada saat wawancara dilaksanakan dan uji kelayakan, calon nomor urut 1 (satu) mengatakan bahwa dia memiliki kedekatan dengan Walikota baik hubungan kerja maupun secara pribadi, berdasarkan hal ini maka dalam penetapan calon sekretaris terpilih Komisioner KPU melampirkan hasil tes dan uji kelayakan tersebut ke KPU Pusat melalui KPU Provinsi Sumbar.

Sekjen KPU Pusat memutuskan dan menetapkan JW sebagai Sekretaris KPU Kota Padang.

Pola rekrutmen yang seharusnya melalui suatu prosedur berdasarkan aturan yang berlaku, ternyata belum bisa digunakan sebagai instrumen yang predictable dalam kaitannya dengan track karier di kemudian hari. Rekrutmen didasarkan pada analisis jabatan yang kemudian dikaitkan dengan analisis kebutuhan SDM untuk mengisi pemenuhan kebutuhan tenaga dalam mengelola kelembagaan atau suatu institusi. Hal tersebut harus jelas, sesuai dengan prosedur dan transparan dengan tidak terjadinya pola rekrutmen yang sifatnya spekulatif.

Menurut Miftah Thoha, jika terjadinya rekrutmen spekulatif, maka proses penempatan, promosi dan seterusnya jadi tidak rasional. Sistem rekrutmen memang harus dilihat secara integral, bukan partial (Miftah Toha:2008). Jika dikaitkan dengan pola rekrutmen Sekretaris KPU Kota Padang, maka berdasarkan hasil wawancara penulis dengan informan penelitian, dimana Dj menjelaskan tentang proses rekrutmen tersebut sebagai berikut:

Berawal dari penarikan saya ke instansi asal, yang awalnya menjabat sebagai Sekretaris KPU Kota Padang dipindahkan ke instansi Pemuda dan Olah Raga Kota Padang sebagai Kepala Bagian, akan tetapi masih tetap melaksanakan tugas di KPU sebagai Plt Sekretaris selama 6 (enam) bulan karena saya belum menerima SK pemberhentian dari KPU Pusat.Saya aktif pada dua instansi, melaksanakan pekerjaan seperti biasa pada kedua instansi yakni KPU Kota Padang dan dinas Pemuda dan Olah Raga Kota Padang. Adanya rangkap jabatan yang saya emban saat itu.Dengan telah ditariknya saya ke instansi asal, maka terjadinya kekosongan jabatan defenitif saat itu dan KPU Kota Padang melakukan koordinasi dengan pihak Pemerintah Kota Padang.

Seperti halnya yang terjadi dalam proses rekrutmen PNS daerah yang dipekerjakan pada lembaga KPU Kota Padang dalam proses penempatan dan promosi jabatan yang pada awalnya telah dilalui berdasarkan prosedur dan mekanisme yang ada, namun pada tahap penetapan terjadinya intervensi dari Pejabat Politik yang mengakibatkan 
tidak jadinya dilantik calon Sekretaris yang telah ditetapkan dengan keputusan Sekjen KPU.

Hal di atas sesuai dengan ketentuan Pasal 79 ayat 2 Peraturan KPU Nomor 05 Tahun 2008 tentang Tata Kerja KPU, yang menyebutkan bahwa pengusulan calon Sekretaris KPU Kota Padang harus terlebih dahulu berkoordinasi dengan Walikota.

Pengusulan JW sebagai calon Sekretaris KPU Kota Padang, pada dasarnya diawali dengan ditariknyaDj sebagai Sekretaris KPU Kota Padang tanpa adanya pemberitahuan dan koordinasi terlebih dahulu oleh pihak Pemerintah Daerah Kota Padang.Hal tersebut berdasarkan surat Nomor : 168/Kpu-Kota/003.435095/X/2014.

Miftah Thoha mengemukakan, bahwa Jalur pengembangan karier ditentukan secara terbuka dan didasarkan pada prinsip merit system atas dasar kompetensi individual calon yang sesuai dengan kompetensi jabatan yang didudukinya tersebut. Jika dasar kompetensi ini tidak dipenuhi, maka secara rekrutmen maupun promosi berarti melanggar prinsip merit system. Selain itu, pengangkatannya didasarkan hasil seleksi dari tim yang dibentuk untuk keperluan tersebut sehingga dimungkinkan terjadinya Intervensi.
Intervensi Politik merupakan upaya yang dilakukan oleh pejabat politik dalam mempengaruhi proses rekrutmen dan promosi birokrat pada jabatan-jabatan birokrasi. Promosi jabatan diartikan sebagai proses pengangkatan PNS ke jenjang jabatan yang lebih tinggi atau lebih luas kewenangan dan tanggungjawabnya dalam lingkup birokrasi tertentu. Dalam proses manajemen SDM, proses promosi jabatan harus didahului dengan melihat spesifikasi jabatan yang akan diisi oleh PNS diorganisasi tersebut.

Konsep Meryt system pada dasarnyadigunakan untuk memilih seseorang dalam jabatan-jabatan karier dalam birokrasi, seperti halnya sekretaris, biro dan bagian-bagian lainnya. Namun jika dikaitkan dengan proses terjadinya intervensi politik dalam menentukan sekretaris, maka yang harus dipahami terlih dahulu adalah Peraturan KPU Nomor 16 Tahun 2015 tentang Pola Karir PNS di Lingkungan Sekretariat KPU di seluruh wilayah Indonesia.

Hal yang harus dipahami oleh Walikota sesungguhnya bahwa Pegawai Pemerintah Daerah yang sudah diperbantukan ke intansi KPU, harus tunduk pada aturan yang ada di KPU dimana atasan langsungnya sudah vertikal yakni Sekjen 
KPU RI dan hubungannya dengan Pemerintah Daerah hanya saja pada tingkat penilaian SKPnya saja karena semua keuangan baik berupa tunjangan maupun honor kegiatan sudah dianggarkan oleh KPU Pusat.

Pada Tahun 2015 terjadinya permasalahan terkait pengisian kekosongan jabatan Sekretaris KPU Kota Padang. Berdasarkan Surat KPU Kota Padang Nomor: 168/KPUKota/003.435095/X/2014 tanggal 23 Oktober 2014 perihal Permintaan nama Calon Sekretaris KPU Kota Padang sesuai dengan Ketentuan Pasal 79 ayat (2) Peraturan KPU Nomor 05 Tahun 2008 tentang Tata Cara Kerja KPU Di seluruh wilayah Indonesia. Berdasarkan Surat tersebut Walikota Padang telah mengeluarkan Surat Nomor: 824/909/BKD-Pdg/2014 tanggal 4 November 2014 perihal Konsultasi Pemindahan Pejabat Struktural Sekretaris KPU Kota Padang, yang mana diusulkan nama-nama untuk pemindahan pengangkatan dan pemberhentian Pejabat Sekretaris KPU Kota Padang yang akan diusulkan ke KPU Pusat di Jakarta, sebagai berikut:

\begin{tabular}{|c|c|c|c|}
\hline No. & Nama/NIP & $\begin{array}{l}\text { Pangkat/ } \\
\text { Gol }\end{array}$ & Jabatan Saai ini \\
\hline 1 & $\begin{array}{l}\text { Fauzil } \\
\text { Mahfud.SH }\end{array}$ & $\begin{array}{l}\text { Penata } \\
\text { TK. } \\
\text { I(III/d) }\end{array}$ & $\begin{array}{l}\text { Kepala Seksi } \\
\text { Kesiswaan } \\
\text { Bidang } \\
\text { Pendidikan Dasar } \\
\text { pada Dinas } \\
\text { Pendidikan Kota } \\
\text { Padang }\end{array}$ \\
\hline
\end{tabular}

\begin{tabular}{|c|l|l|l|}
\hline 2 & $\begin{array}{l}\text { Junita Witri. } \\
\text { SH, M.Si }\end{array}$ & $\begin{array}{l}\text { Penata } \\
\text { TK. } \\
\text { I(III/d) }\end{array}$ & $\begin{array}{l}\text { Kepala Seksi } \\
\text { Pembinaan } \\
\text { Organisasi } \\
\text { Kepemudaan } \\
\text { pada Dinas } \\
\text { Pemuda dan Olah } \\
\text { Raga Kota } \\
\text { Padang }\end{array}$ \\
\hline 3 & $\begin{array}{l}\text { Drs. Imran } \\
\text { Rasyid }\end{array}$ & $\begin{array}{l}\text { Penata } \\
\text { TK. } \\
\text { I(III/d) }\end{array}$ & $\begin{array}{l}\text { Lurah Air Manis } \\
\text { Kec. Padang } \\
\text { Selatan Kota } \\
\text { Padang }\end{array}$ \\
\hline
\end{tabular}

Pejabatyang diusulkan

Pembahasan atas hasil tes kelayakan dan kepatutan Calon Sekretaris KPU Kota Padang yang berasal dari lingkungan Sekretariat KPU Kota Padang sebagaimana tertuang dalam Berita Acara Rapat Pleno KPU Kota Kota Padang Nomor: 5/BA/KPUPDG/II/2015 tanggal 26 Februari 2015, menetapkan nama-nama dan komposisi Calon Sekretaris KPU Kota Padang yang telah disetujui dan ditetapkan sesuai dengan Berita Acara Rapat Pleno Anggota KPU Kota Padang Nomor: 1/BA/KPU-PDG/I/2015 sebagai usulan final KPU Kota Padang kepada KPU RI.

Hasil wawancara dengan beberapa informan, menyatakan bahwa kronologis proses terjadinya intervensi terkait pengangkatan Sekretaris KPU Kota Padang sebagai berikut "bahwa JWmerupakan calon Sekretaris KPU Kota Padang yang dipilih dan ditetapkan oleh Sekjen KPU RI, tetapi tidak jadi dilantik dengan alasan tidak mendapatkan izin dari atasan langsung yakni Pejabat Politik". Dalam uraian 
selanjutnya dikemukakan hal-hal yang berkaitan dengan proses penetapan sekretaris KPU Padang.

Dalam hal ini secara tertulis Pemerintah Daerah Kota Padang telah menyetujui untuk dilakukannya proses tahapan lebih lanjut. KPU Kota Padang melakukan Fit and Proper test serta uji kelayakan terhadap 3 (tiga) orang nama yang dicalonkan sebagai Sekretaris KPU Kota Padang. 3 (tiga) orang nama yang dicalonkan sebagai Sekretaris KPU Kota Padang mengikuti semua rangkaian proses yang ada mulai dari melengkapi administrasi, tes tertulis, wawancara dan sampai pada tahan penetapan hasil. Dari hasil Fit and Proper test serta uji kelayakan terhadap 3 (tiga) orang nama yang dicalonkan sebagai Sekretaris KPU Kota Padang, dimana KPU Kota Padang meneruskan hasilnya ke KPU Provinsi dengan melengkapi semua dokumen proses yang dilalui, mulai dari proses permintaan nama hingga tahap hasil seleksi yang dilalui. KPU Provinsi menidaklanjuti dan kemudian mengirimkan hasil Fit and Proper test serta uji kelayakan terhadap 3 (tiga) orang nama yang dicalonkan sebagai Sekretaris KPU Kota Padang ke KPU Pusat.

Berdasarkan hal tersebut maka KPU Pusat memilih salah satu nama dari
3 (tiga) orang nama yang dicalonkan sebagai Sekretaris KPU Kota Padang berinisial JW dan yang menjadi dasar bagi KPU Pusat untuk menetapkan JW sebagai Sekretaris KPU Kota Padang adalah Hasil Fit and Proper test dan berdasarkan pada pengalaman dibidang kepemiluan, dimana JW pernah menjabat sebagai Kasubbag Teknis di KPU Kota Padang selama 4 (empat) tahun. Selain itu JWsatu-satunya dari 3 (tiga) orang calon yang telah menyelesaikan S2, yang merupakan salah satu dari persyaratan yang ada. Tahapan selanjutnya KPU Pusat mengeluarkan SK JW, yang salinannya sudah diserahkan kepada yang bersangkutan.

KPU Kota Padang diminta oleh Sekjen KPU untuk segera mempersiapkan agenda pelantikan, yang saat itu diwakilkan kepada KPU Provinsi Sumatera Barat. Pada tahap akan dilaksanakannya pelantikan, Pemda Kota Padang melalui Sekda secara lisan menyampaikan keberatan dan tidak mengizinkan calon terpilih berinisial JW untuk menghadiri pelantikan. Sekda Kota Padang meminta JW untuk membuat surat pengunduran diri secara tertulis yang ditujukan kepada pihak KPU Kota Padang, bertujuan untuk menghentikan proses pelantikan. Hal ini 
dibenarkan oleh JW berdasarkan hasil wawancara yang peneliti lakukan menjelaskan bahwa:

Pada tahap akan dilaksanakannya pelantikan, Walikota melalui Sekda secara lisan menyampaikan keberatan dan tidak mengizinkan saya untuk menghadiri pelantikan.

Sekda Kota Padang meminta saya untuk membuat surat pengunduran diri secara tertulis yang ditujukan kepada pihak KPU Kota Padang, bertujuan untuk menghentikan proses pelantikan.

Saya tidak menyetujui untuk membuat surat pengunduran diri secara tertulis, karena saya merasa tidak mempunyai permasalahan apapun dengan Pimpinan tertinggi saat itu yakni bapak Walikota dan saya merasa bahwa diri saya layak untuk menempati posisi jabatan yang ditawarkan kepada saya dengan serangkaian tes yang telah dialui.

Terjadinya intervensi terhadap lembaga KPU Kota Padang dalam hal penempatan calon Sekretaris KPU Kota Padang dikuatkan dengan hasil wawancara yang peneliti dilakukan dengan informan berinisial JW, dia mengatakan bahwa "Saya tidak mengetahui secara langsung alasan Pimpinan tertinggi kenapa tidak lagi memberikan saya izin untuk datang pada acara pelantikan yang telah dipersiapkan oleh KPU Kota Padang.Saya marasa Walikota melakukan intervensi terhadap lembaga KPU Kota Padang dalam penetapan Calon Sekretaris KPU Kota Padang, dimana pada proses awal telah mendapatkan persetujuan dan izin untuk mengikuti seleksi, tetapi setelah ditetapkannya saya sebagai Calon Sekretaris KPU Kota Padang terpilih, melalui Sekda dimana Walikota meminta saya mengundurkan diri secara tertulis dan Walikota Padang tidak mengizinkan saya untuk datang dan hadir pada pelantikan Sekretaris KPU Kota Padang tersebut"

KPU Kota Padang melakukan Fit and proper test terhadap 3 (tiga) orang nama calon Sekretaris, dan bersadarkan hasil nilai urut dimana JW merupakan peringkat nomor urut 2 (dua).Berdasarkan nilai tes tertinggi nomor urut 1 (satu) adalah LDYPPemerintah Daerah Kota Padang dalam hal ini Walikota menginginkan KPU untuk mengeluarkan SK Penetapan dan melantikan LDYP, dengan alasan bahwa dari hasil nilai tes tertinggi adalah LDYPPemerintah Daerah Kota Padang dalam hal ini Walikota tidak melakukan intervensi terhadap KPU hanya intervensi tersebut terjadi dalam hal regulasi saja, dimana Pemerintah Daerah Kota Padang hanya meginginkan KPU untuk menetapkan calon nomor urut 1 (satu) yakni LDYP sebagai Sekretaris KPU Kota Padang berdasarkan nomor urut tertinggi.

Prosedur dalam pengisian jabatan Sekretaris di Lingkungan KPU Kota Padang harus berdasarkan UU 15 Tahun 2011 tentang Pemiluterakhir di diubah dengan UU 17 Tahun 2017, Pasal 59. 
Terjadinya intervensi politik dalam penentuan

posisi jabatanstruktural dan jenjang karir di lingkungan KPU Kota Padang oleh unsur Pemerintahan dan Pejabat Politik bagi birokrat hendaknya didasarkan pada prinsip-prinsip meryt sistem yaitu manajemen kepegawaian dalam birokrasi yang lebih memfokuskan pada aspek kompetensi pegawai sebagai basis dalam melakukan rekrutmen dan promosi pegawai di jajaran birokrasi. Penerapan meryt sistem ini perlu didukung dengan kebijakanmengenai klasifikasi jabatan, standar kompetensi, standar kinerja, pola karier dan remunerasi yang mendorong pencapaian kinerja. Dalam perspektif ini, reformasi politik dan birokrasi harus menjangkau pada upaya membatasi ruang gerak kekuasaan pejabat politik dan membangun kemandirian dan profesionalitas birokrasi pemerintahan, sehingga tidak memberikan ruang terjadinya penyalahgunaan kekuasaan pejabat politik.

Beranjak dari gambaran penentuan unsur pimpinan KPU Kota Padang, khususnya penentuan sekretaris KPU Kota Padang, dapat dikatakan terjadinya intervensi politik dari Pemerintahan dan berjalannya birokrasi itu sendiri.Hal ini jika dikaitkan dengan makna suatu intervensi itu sendiri yang mencakup adanya tidakan campur tangan yang dilakukan, baik pada bidang ekonomi, sosial, budaya, politik maupun bidang kemasyarakatan lainnya.Dalam arti, bahwa intervensi politik yang dimaksud merupakan upaya yang dilakukan oleh pejabat politik dalam mempengaruhi proses rekrutmen dan promosi birokrat pada jabatan-jabatan birokrasi itu sendiri (Azhari:2011)

\section{Kepentingan Politik Dibalik Intervensi Terhadap KPU Kota Padang}

Pada dasarnya konsep biroksi dalam bidang publik, dimaknai sebagai proses dan sistem yang diciptakan secara rasional untuk menjamin mekanisme dan sistem kerja yang teratur, pasti dan mudah dikendalikan serta sesuai dengan ketentuan yang berlaku sebagai acuan dalam menjalani suatu putusan. Dalam arti, bahwa birokrasi terdapatnya rambu-rambu bahwa putusan atau kebijakan yang diambil mempunyai yurisdiksi yang jelas, tegas dan tanggungjawab yang yuridis yang memperjelas batasan kewenangan-kewenanganyang ada.

Netralitas birokrasi menuntut diterapkannya pola merit system( Malayu S. P. Hasibun 2007:103)dalam manajemen 
kepegawaian. Undang-Undang Nomor 5 Tahun 2014 tentang Aparatur Sipil Negara menekankan pada pelaksanaan merit system secara konsekuen. Sitem ini menekankan pada kompetensi dan profesionalitas calon yang direncanakan menduduki jabatan yang sama atau selaras dengan kompetensi jabatannya. Selain itu, moralitas dari calon juga menjadi pertimbangan dalam proses pengangkatan dan promosi jabatan.

Dalam persyaratan khusus, bahwa calon Sekretaris KPU Kota Padang yang akan dipilih harus memiliki pengalaman, memahami pengetahuan di bidang Pemilihan Umum. Dalam Pasal 59 ayat 4 UU Nomor 15 Tahun 2011 tentang Pemilu terakhir diubah denganUU 17 Tahun 2017, bahwa Sekretaris Jendral KPU memilih 1 (satu) orang Sekretaris KPU Kota Padang dari 3 (tiga) orang calon dan selanjutnya ditetapkan dengan Keputusan Sekretaris Jenderal KPU. artinya yang mempunyai kewenangan mutlak untuk memilih 1 (satu) orang Sekretaris KPU Kota Padang adalah Sekretaris Jendral KPU RI.

Beranjak dari uraian di atas, jika dikaitkan dengan penentuan sekretaris KPU Kota Padang, bertentangan dengan ketentuan pengaturannya. Artinya, bahwa dalam penetapan calon sekretaris terpilih terjadi ketidak konsistenan dari aturan yang berlaku tersebut, dimana Pejabat Politik menolak Keputusan Sekjen KPU RI untuk dilakukannya pelantikan terhadap calon yang berinisial JW dan meminta KPU Kota Padang untuk menetapkan calon dengan nomor urut 1 (satu) berinisial FM.

Kebijakan yang dilakukan sebagaimana dimaksudkan di atas, menunjukan bahwa Pejabat Politik melakukan intervensi terhadap kelembagaan KPU Kota Padang. Keadaan ini sesuai dengan hasil wawancara dengan beberapa informan, bahwa telah terjadinya "kepentingan politik" dalam proses penyelenggaraan pemilu dibalik intervensi Pemda Kota Padang terhadap KPU Kota Padang.

Dari hasil wawancara yang peneliti lakukan dengan JW menyatakan bahwa "Proses penepatan Sekretaris terjadi pada masa Tahapan Gubernur Tahun 2015, yang mana Gubernur Sumbar merupakan orang dari Partai PKS dan Walikota Padang juga merupakan orang yang berasal dari Partai PKS, dimana jabatan yang ada di Pemerintahan Daerah merupakan jabatan politik yang dipertaruhkan banyak orang. Untuk melangengkan kekuasaanya pada Pemilihan Walikota yang akan datang pada Tahun 2018, hal ini terbukti dimana Sekretaris 
yang duduk saat ini merupakan orang yang dekat dengan Walikota"

$$
\text { Intervensi dalam sebuah }
$$

birokrasi di negara ini bukan lagi hal baru, malah cederung menjadi sebuah kebiasaan. Namun, beberapa hal harus diingat bahwa birokrasi sendiri adalah inti dari sebuah pemerintahan. Intervensi adalah beberapa upaya atau tindakan untuk melakukan tekanantekanan tertentu kepada pihak lain untuk mencapai sesuatu yang lebih baik. Secara umum intervensi merupakan tindakan campur tangan yang dilakukan suatu negara kepada negara lain, baik pada bidang ekonomi, sosial, budaya, politik maupun bidang kemasyarakatan lainnya.

$$
\text { Adi Fahrudin }
$$

mendefinisikan tiga tingkatan intervensi komunitas (community work) yang menggambarkan cakupan yang berbeda dimana intervensi dapat diterapkan, pembagian tersebut ialah:

\section{a.Grassroot ataupun neighbourhood}

b. Local agency dan inter-agency work

c. Regional dan national community planning work

Berdasarkan apa yang dijelaskan Adi Fakhrudin diatas tiga tingkatan intervensi komunitas (community work) yang ada salah satunya ialah Local agency dan inter-agency work (pelaku perubahan melakukan intervensi terhadap organisasi payung di tingkat lokal, provinsi ataupun di tingkat yang lebih luas, bersama jajaran pemerintah yang terkait serta organisasi nonpemerintah yang berminat terhadap hal tersebut), jika dikaitkan dengan permasalahan yang terjadi dapat dilihat dari adanya penolakan terhadap keputusan yang telah diambil oleh KPU selaku lembaga yang independen (mandiri) yang dilakukan oleh Pejabat Politik merupakan intervensi terhadap organisasi.

Tujuan Intervensi Politik untuk memposisikan Sekretaris KPU adalah untuk memperoleh informasi berkaitan dengan tahapan pemilu agar memuluskan semua proses pelaksanaan pilkada yang akan datang, karena KPU sebagai pemegang rahasia seluruh administrasi untuk pemilu. Intervensi itu selalu terjadi, namun susah untuk dibuktikan secara administrasi, karena intervensi itu dilakukan kepada personal dengan pemanggilan secara langsung terhadap siapa yang ingin diposisikan.Jabatan strategis yang ada dibirokrasi merupakan jabatan politik karena banyaknya unsur kepentingan disana, saat ini semua yang menjabat merupakan orang kepercayaan Walikota. PKS sangat dominan sekali di Kota Padang, karena mulai dari Guberbur hingga Walikota merupakan orang PKS, jadi mereka hanya menginginkan orang-orang 
yang satu pandangan dengannyalah yang akan diberikan posisi yang strategis.

Kekuasaan

birokrasi

dimanfaatkan oleh pengambil kebijakan untuk melakukan intervensi politik dalam penentuan Sekretaris KPU. Dengan kewenangan dan kekuasaan sebagai kepala daerah membuat pemangku jabatan publik mudah mempengaruhi dan menekan birokrasi untuk kepentingan politiknya. Hal ini sesuai dengan apa yang dikemukakan oleh Rozi dalam uraian sebelumnya, yakni; "politisasi birokrasi merupakan gejala yang melibatkan birokrasi secara langsung dan terang-terangan untuk menjadi pendukung dan anggota organisasi peserta pemilu guna memperoleh atau mempertahankan kekuasaan di parlemen dan eksekutif".

Hal tersebut bertentangan dengan upaya membangun budaya dan etika professional di kalangan birokrat dan menghilangkan ketergantungan politik antara politisi dengan birokrasi. Sehingga memberi kepastian para birokrat dalam bertugas dan memberi motivasi untuk berprestasi serta untuk mewujudkan nilai-nilai yang terkandung dalam kepentingan publik melalui kemampuan profesional sesuai dengan prinsip meryt systemyaitu manajemen kepegawaian dalam birokrasi yang lebih memfokuskan pada aspek kompetensi dan kompetisi pegawai sebagai basis dalam melakukan rekrutmen dan promosi pegawai di jajaran birokrasi.

Sejalan dengan teori intervensi politik yang diuangkapkan oleh Azhari (2011) dalam tulisannya mengatakan bahwa intervensi intervensi politik terhadap birokrasi adalah tindakan yang dilakukan oleh pejabat-pejabat politik semata-mata untuk kepentingan partai politik dan individu pejabat politik tertentu dalam melanggengkan kekuasaannya.

\section{SIMPULAN}

Intervensi politik yang dilakukan oleh Pejabat Politik untuk melanggengkan kekuasaannya, dilakukan secara langsung yang berakibat mempengaruhi hasil keputusan yang telah di tetapkan oleh Sekjen KPU. Intervensi yang dilakukan secara lisan berupa pemanggilan calon pejabat yang akan mengisi suatu jabatan atau yang sedang diusulkan dan meminta kepada calon Sekretaris terpilih untuk membuat surat pengunduran diri dengan tujuan menghentikan semua proses pemilihan calon Sekretaris yang telah ditetapkan dengan Surat Keputusan Sekjen KPU. hal ini memunculkan permasalahan baru atas penolakan Pemda Kota Padang 
yang merupakan bentuk intervensi politik.

\section{Saran}

$$
\text { Bagi KPU agar terciptanya }
$$
suasana kerja yang baik dan kondusif diharapkan dapat lebih memberdayakan PNS organiknya untuk menduduki jabatan struktural yang ada di lingkungan KPU, karena dilihat dari berbagai aspek dimana PNS organik KPU lebih memahami bidang kepemiluan dibandingkan dengan PNS yang dipekerjakan pada lembaga KPU.

Diharapkan kepada KPU untuk mengembalikan PNS daerah yang diperbantukan ke instansi asal, agar KPU dapat mengelola SDM sendiri yang bertujuan untuk menghindari terjadinya intervensi dari pihak lain khususnya Pejabat Politik sebagai pemangku kepentingan.

\section{Daftar Pustaka}

Adi Fahrudin. 2014. Pengantar Kesejahteraan Sosial. Bandung. Rafika Aditama. Hlm. 82.

Azhari, 2011, Mereformasi Birokrasi Publik, Pustaka Pelajar, Yogyakarta, Hlm. 45

Ramlan Surbakti, Kris Nugroho. 2015. Studi tentang Desain Kelembagaan Pemilu yang Efektif. Kemitraan Partnership bagi Pembaruan Tata Pemerintahan: Jakarta. Jakarta. Hlm. 57.

Nurul Ulfatin. 2017. Metode Penelitian. Malang: Media Nusa Creative. Hlm. 25.

Said, M. Mas'ud. 2007. Birokrasi di Negara Birokratis. Universitas Muhammadiyah Malang Press. Malang. Hlm.2.
Syafuan Rozi. 2006. Zaman Bergerak, Birokrasi Dirombak: Potret Birokrasi dan Politik di Indonesia. Jakarta: P2P-LIPI. HIm. 17.

Miftah Thoha. 2008. Birokrasi Pemerintah di Era Reformasi. Jakarta. Kencana. HIm. 77

Undang-Undang Nomor 15 Tahun 2011tentang Penyelenggara Pemilihan Umum.

Undang-Undang Nomor 5 Tahun 2014 tentang Aparatur Sipil Negara.

Undang-Undang Nomor 7 Tahun 2017 tentang Pemilihan Umum.

Peraturan Pemerintah Nomor 100 Tahun 2000 tentang Pengangkatan Pegawai Negeri Sipil Dalam Jabatan Struktural.

Peraturan Pemerintah Nomor 9 Tahun 2003 tentang Wewenang Pengangkatan, Pemindahan, Pemberhentian Pegawai Negeri Sipil.

Peraturan KPU Nomor 05 Tahun 2008 tentang Tata Kerja Komisi Pemilihan Umum, Komisi Pemilihan Umum Provinsi dan Komisi Pemilihan Umum Kabupaten/Kota, sebagaimana diubah dengan Peraturan KPU Nomor 8 Tahun 2019 tentang Tata Kerja Komisi Pemilihan Umum, Komisi Pemilihan Umum Provinsi dan Komisi Pemilihan Umum Kabupaten/Kota

Peraturan KPU Nomor 06 Tahun 2008 tentang Susunan Organisasi dan Tata Kerja Sekretariat Jenderal Komisi Pemilihan Umum, Sekretaris Komisi Pemilihan Umum Provinsi dan Sekretariat Komisi Pemilihan Umum Kabupaten/Kota.

Peraturan KPU Nomor 16 Tahun 2015 tentang Perubahan Atas Peraturan Komisi Pemilihan Umum Nomor 02 tahun 2012 tentang Pola Karir Pegawai Negeri Sipil di Lingkungan Sekretariat Jenderal Komisi Pemilihan Umum, Sekretariat Komisi Pemilihan Umum Provinsi dan Sekretariat Komisi Pemilihan Umum Kabupaten/Kota.

Keputusan Sekretaris Jenderal Komisi Pemilihan Umum Nomor 345/Kpts/Setjen/TAHUN 2014 tentang Pendelegasian Wewenang di Bidang Kepegawaian kepada Pejabat pada Sekretariat Jenderal KPU, Sekretariat KPU Provinsi dan Sekretariat KPU Kabupaten/Kota. 